\title{
Editorial
}

\section{CULTURA ORGANIZACIONAL EN SEGURIDAD}

A finales del mes de marzo un trabajador de la mina Radomiro Tomic, perteneciente a Codelco, falleció producto de un derrumbe. Este hecho, que de acuerdo al informe de la minera fue un "Accidente Fortuito", no fue considerado de esta manera por el sindicato de la empresa, el cual concluyó que la compañía habría sido negligente en cuanto a las condiciones de seguridad que se le brindaron al trabajador para operar dentro de la mina. Este accidente, que sin duda pudo evitarse, trajo consecuencias importantes dentro de la organización; incluyendo un paro de los trabajadores de la compañía y finalmente la destitución del Gerente General. Lo anterior, sin la intención de hacer mayores juicios sobre los hechos descritos y conocidos por la opinión pública, refleja, a mi parecer, el estado en que se encuentra la cultura organizacional en seguridad en nuestro país y específicamente en Minería. Lo que pudimos observar, sin entrar en el debate político de que este es un año electoral, fue cómo los trabajadores frente a un hecho lamentable acaecido dentro de la mina se manifestaron en contra de la gestión en seguridad que se estaba llevando a cabo dentro de la faena, llegando a exigir la renuncia de su gerente general, quien, muchos se preguntarán, ¿qué responsabilidad pudo haber tenido él en el derrumbe de una parte del cerro? Sin duda, que él no fue el causante de tamaño accidente, pero sí es responsable de la cultura en seguridad que reina dentro de una organización. El hecho de privilegiar en muchas ocasiones la productividad por sobre la seguridad suele pasar la cuenta y lamentablemente esto bien lo saben en RT. En Chile, el rubro de la minería es el más seguro, tiene los índices más bajos de Accidentabilidad, como podrán ver en la estadística de Accidentabilidad del año 2012.

Este indicador, que habla muy bien de la gestión en seguridad que se realiza en la industria, con trabajadores comprometidos con la seguridad y con la productividad de sus compañías, nos invita a seguir mejorando y continuar liderando en nuestro país la protección y la vida de los trabajadores. Lo anterior lo planteo debido a un simple análisis que creo es fácil de compartir: un accidente en minería no es lo mismo que un accidente en un banco, en un supermercado, o en la agricultura. Lamentablemente, por la naturaleza y las dimensiones de los equipos que se requieren, la minería ocupa el tercer lugar dentro los rubros con más fatalidades.

En síntesis, las estadísticas, por una parte positivas $\mathrm{y}$ finalmente negativas, nos invitan a seguir trabajando en seguridad para proteger la vida de los trabajadores. Una muerte de un trabajador implica una serie de desbarajustes sociales y económicos lamentables que son importantes de prevenir. 